\title{
Physical Quality and Digestibility In Vitro Determination of Green Pellet Concentrate Based on Indigofera zollingeriana
}

\author{
Tarigan $\mathrm{A}^{1}$, Ginting $\mathrm{SP}^{2}$, Arief $\mathrm{II}^{3}$, Astuti $\mathrm{DA}^{4}$, Abdullah $\mathrm{L}^{4}$ \\ ${ }^{1}$ Graduate School of Animal Nutrition and Feed Science, Bogor Agricultural University, Jl.Agatis, Darmaga Campus, Bogor 16680-Indonesia \\ ${ }^{2}$ Indonesia Goat Research Station, Sungai Putih \\ ${ }^{3}$ Department of Production Science and Animal Husbandry Technology, Faculty of Animal Science, Bogor Agricultural University \\ ${ }^{4}$ Department of Animal Nutrition and Feed Technology, Faculty of Animal Science, Bogor Agricultural University, \\ Jl. Agastis, Darmaga Campus, Bogor 16680-Indonesia \\ E-mail: anditarigan77@gmail.com
}

(received 19-06-2017; revised 05-09-2017; accepted 11-09-2017)

\begin{abstract}
ABSTRAK
Tarigan A, Ginting SP, Arief II, Astuti DA, Abdullah L. 2017. Identifikasi kualitas fisik dan pelet konsentrat hijau berbasis Indigofera zollingeriana secara in vitro. JITV 22(3): 114-123. DOI: http://dx.doi.org/10.14334/jitv.v22i3.1651

Penelitian ini bertujuan untuk mengetahui kualitas fisik dan kecernaan pelet konsentrat hijau berbasis I.zollingeriana secara in vitro. Komposisi pakan berupa pelet konsentrat hijau mengandung I. zollingeriana dan C. calothyrsus pada berbagai kombinasi sebagai berikut : 1) I. zollingeriana/C. calothyrsus $(90 / 0 ; \mathrm{R} 0), 2)$ I. zollingeriana/C. calothyrsus $(75 / 15 ; \mathrm{R} 1)$, 3) I. zollingeriana/C. calothyrsus (60/30; R2) dan 4) I. zollingeriana/C. calothyrsus (45/45; R3). Penelitian kualitas fisik pelet konsentrat hijau dilakukan dengan menggunakan rancangan acak lengkap dengan empat perlakuan pelet konsentrat hijau masing-masing tiga ulangan. Penelitian kecernaan pelet konsentrat hijau dilakukan secara in vitro fermentasi rumen dilakukan menggunakan rancangan acak kelompok dengan empat perlakuan pelet konsentrat hijau dengan tiga kelompok cairan rumen berbeda. Hasil penelitian memperlihatkan bahwa kualitas fisik pakan konsentrat hijau pelet yang mengandung komposisi I. zollingeriana/C. calothyrsus $(60 / 30 ; \mathrm{R} 2)$ memiliki karakter fisik terbaik (aktivitas air $=0.58$; ukuran partikel $=12.69 \mathrm{~mm}$; sudut tumpukan $=21.01^{\circ}$; ketahanan benturan $=99.78 \%$; ketahanan gesekan $=90.42 \%$; kerapatan tumpukan $=590 \mathrm{~kg} / \mathrm{m}^{3}$ ) dibandingkan dengan pelet mengandung komposisi lainnya. Kualitas pakan berdasarkan kecernaan secara in vitro, bahan kering dan bahan organik memperlihatkan pola yang sama yaitu R0 lebih tinggi $(\mathrm{P}<0.05)$ dibandingkan dengan perlakuan yang lain, sedangkan kecernaan In Vitro protein kasar memperlihatkan R0, R1 dan R2 $(\mathrm{P}>0.05)$, namun $(\mathrm{P}<0.05)$ lebih tinggi dari perlakuan R3. Tidak terdapat perbedaan $\mathrm{pH}$ dan total bakteri pada keempat jenis pakan konsentrat hijau pelet. Perlakuan R3 memiliki konsentrasi $\mathrm{NH}_{3}$, VFA dan produksi gas total paling rendah $(\mathrm{P}<0.5)$ dibandingkan dengan perlakuan $\mathrm{R} 2, \mathrm{R} 1$ dan $\mathrm{R} 0$. Dapat disimpulkan bahwa masuknya Calliandra calothyrsus tidak mengubah kualitas fisik green pellet. Namun, peningkatan kadar C. calothyrsus meningkatkan RUP dan mengurangi kecernaan, N-NH3 dan total VFA.
\end{abstract}

Kata Kunci: Indigofera zollingeriana, Calliandra calothyrsus, Pelet, Pakan

\section{ABSTRACT}

Tarigan A, Ginting SP, Arief II, Astuti DA, Abdullah L. 2017. Physical quality and digestibility in vitro determination of green pellet concentrate based on Indigofera zollingeriana. JITV 22(3): 114-123. DOI: http://dx.doi.org/10.14334/jitv.v22i3.1651

This study aims to determine the physical quality and digestibility of green pellet concentrate based on I. zollingeriana. The composition of green pellet concentrate feed contains I. zollingeriana and $C$. calothyrsus in the following combinations: 1$) I$. zollingeriana /C. calothyrsus (90/0; R0), 2) I. zollingeriana/C. calothyrsus (75/15; R1), 3) I. zollingeriana/C. calothyrsus (60/30; R2) and 4) I. zollingeriana / C. calothyrsus (45/45; R3). The physical quality study of green pellet concentrate was performed using a completely randomized design with four types of green concentrate as treatments of three replications. Green pellet concentrate studies conducted in vitro rumen fermentation were performed using in a randomized block design with four treatments and three sources of liquid rumen as a block. The results of the experiments conducted with pellet criteria containing I. zollingeriana/C. calothyrsus composition $(60 / 30 ; \mathrm{R} 2)$ have the best physical character (water activity $=0.58$; particles size $=$ $12.69 \mathrm{~mm}$; degree value angles $=21.01^{\circ}$; collision endurance $=99.78 \%$; endurance friction $=90.42 \%$; bulk density $=590$ $\mathrm{kg} / \mathrm{m} 3$ ) compared to the other treatments. The quality of diet based on digestibility in vitro, dry matter and organic material having a pattern equal to $\mathrm{R} 0$ is higher $(\mathrm{P}<0.05)$ compared with other treatments, while the rough digestibility of In Vitro protein is seen R0, R1, and R2 $(\mathrm{P}>0.05)$, but $(\mathrm{P}<0.05)$ was higher than the treatment of R3. There was no difference of $\mathrm{pH}$ and total bacteria on green pellet concentrate type. The treatment of R3 has the lowest NH3, VFA and total gas concentration $(\mathrm{P}<0.5)$ compared with R2, R1 and R0. It can be concluded that inclusion of Calliandra calothyrsus did not change physical quality of green pellets. However, increasing level of $C$. calothyrsus increased RUP and reduced digestibility, N$\mathrm{NH}_{3}$, and total VFA.

Key Words: I. zollingeriana, Calliandra calothyrsus, Pellets, Feed 


\section{INTRODUCTION}

One of the important inhibiting factors in ruminant production is the scarcity of feed due to its high price and its fluctuation in quantity and nutritional qualities. (Van et al. 2005; Olafadehan \& Adewumi 2009). During the last twenty years, it was reported that there was an increase in cost of feeding of ruminant production from $60 \%$ of total production cost $\left(1990^{\prime s}\right)$ to $64-66 \%$ (the $2000^{\prime s}$ ) and $65-75 \%$ (the $2010^{\text {'s }}$ ) because of a tendency to use feed concentrates at any stage of production (Kholif et al. 2015). Leguminous forages have been known widely to have a concentrate feed characteristic due to its high nutrient contents (crude protein, vitamin, and some mineral) and its highly DM digestibility. Indigofera zollingeriana is a leguminous tree that contains high crude protein $(25-31 \%)$ and high (71-86.3\%) DM digestibility (Tarigan et al. 2010; Abdullah et al. 2012a). The use of I. zollingeriana as a feed supplement (Tarigan \& Ginting 2011) or as a sole forage gave a good growth rate of goats (Ginting et al. 2010). In dairy goats, the use of I. zollingeriana leaves pellets improved milk production and efficiency of feed and nutrient utilization (Abdullah et al. 2012b). On the other hands, the potential use of Calliandra calothyrsus as feed-in ruminant production have been widely reported (Norton 1994; Hess et al. 2008; Jayanegara et al. 2011a). This forage is known for its high tannin content. While the protein-tannin complexes may decrease ruminal protein degradation and may lead to increase the flux of dietary protein for absorption in the intestine (Patra \& Saxena 2011; Theodoridou et al. 2010), the high tannin level may also result in reduced feed intake and digestibility. However, the combination of such high-tannin content with highly fermentable and low tannin content will improve microbial protein synthesis and protect the dietary protein without adversely affecting microbial growth efficiency and overall animal productivity (Soltan et al. 2012).

Feed processing such as pelleting may improve the physical (Svihu 2011; Svihu \& Zimonja 2011), and nutritional characteristics of the feed ingredient through

Table 1. The composition of green concentrate pellets the increased starch availability by gelatinization (Solanas et al. 2005; Svihu \& Zimonja 2011), thus increasing its fermentation rate (Solanas 2008; Bertipaglia et al. 2010). This study aimed to evaluate the physical and in vitro nutritional qualities of green concentrate pellet composed of low tannin forages ( $I$. zollingeriana) and high tannin forage (C. calothyrsus) of various composition.

\section{MATERIALS AND METHODS}

The study was conducted at the Research Institute for Goat Production, Sungai Putih, North Sumatera from July to November 2016. Indigofera zollingeriana and Calliandra calothyrsus were harvested at 60 dayintervals and were cut 1.0 meter above ground level. The leaves were wilted by air-dried for 3-4 hours under the sun and ground using grinder with $1.0 \mathrm{~mm}$ screening size. Green concentrate pellets were formulated as follows: $90 \%$ I. zollingeriana $+0 \% C$. calothyrsus (R0), $75 \%$ I. zollingeriana $+15 \%$ C. calothyrsus (R1), $60 \%$ I. zollingeriana $+30 \%$ C. calothyrsus (R2) and $45 \%$ I.zollingeriana $+45 \% C$. calothyrsus (R3). The complete composition of the green concentrate is shown in Table 1. Pellet was produced using pelleting machine to yield green concentrate pellet of $5 \mathrm{~mm}$ diameter.

\section{Chemical analysis}

Dry matter, Kjeldahl N, crude fiber, and ash was analyzed according to AOAC (2005). The content NDF and ADF) were analyzed according to the method Van Soest (1991) and total tannin was analysed according to the folin-ciocateu method (Makkar 2003).

\section{Physical qualities}

Activity water (Aw) was measured using Aw meter that has been calibrated. Particles size was determined using vibrator ball mill with mesh/sieve of $4,8,16,30$,

\begin{tabular}{|c|c|c|c|c|}
\hline \multirow{2}{*}{ Ingredients } & \multicolumn{4}{|c|}{ Ratio (\%) } \\
\hline & R0 & $\mathrm{R} 1$ & $\mathrm{R} 2$ & $\mathrm{R} 3$ \\
\hline I. zollingeriana meal & 90 & 75 & 60 & 45 \\
\hline C. calothyrsus meal & 0 & 15 & 30 & 45 \\
\hline Cassava meal & 5 & 5 & 5 & 5 \\
\hline Molasses & 3 & 3 & 3 & 3 \\
\hline Premix & 1 & 1 & 1 & 1 \\
\hline Salt & 1 & 1 & 1 & 1 \\
\hline
\end{tabular}


$50,100,400$ according to the method of Syarief \& Halid (1993). The determination of angles of heap was performed according to Khalil (1999b). The endurance of green concentrate pellets was tested using shatter test by throwing pellets of known weights over a plates iron according the method of Balagopolan et al. (1988). The endurance pellets to friction (durability) were determined using the tumbling method as described by Fairfield (1994). The density was measured by pouring out samples of known weights into measuring glasses, and density was calculated as the ratio sample weight to the volume it occupies in the glass meter $\left(\mathrm{kg} / \mathrm{m}^{3}\right)$ according to Khalil (1999a).

\section{In vitro ruminal fermentation}

In vitro fermentation was done according to the method Tilley \& Terry (1963). Rumen fluid was obtained from goats in the slaughterhouse. Rumen liquid was put into a flask surrounding hot water to maintain a temperature in flask between $39-40^{\circ} \mathrm{C}$. Samples $(0.5 \mathrm{~g})$ of each feed treatment was put into fermentor tube into which $18.0 \mathrm{ml}$ artificial saliva solution (McDougall) was added (temperature $39-40^{\circ} \mathrm{C}$ and $\mathrm{pH}$ 6.5-6.9), and then inoculated with $12 \mathrm{ml}$ of rumen liquid. $\mathrm{CO}_{2}$ added to the flask for \pm 30 seconds in order to maintain the anaerobic condition and the tube was covered with rubber with one direction out of ventilation. Tube fermentor then inserted into a shaker water bath at a temperature of $39^{\circ} \mathrm{C}$ and incubated for four hours. $\mathrm{NH}_{3}$ concentration was determined according to the Conway micro diffusion method (Department of Dairy Science 1966), the VFA total was determined by a steam distillation method (Department of Dairy Science 1966), and $\mathrm{pH}$ was measured using a $\mathrm{pH}$ meter.

After 48 hours of incubation, the rubber cover was opened and $0.2 \mathrm{ml}$ saturated $\mathrm{HgCl}_{2}$ was dropped (3-2 drops). The tubes were centrifuged at $5000 \mathrm{rpm}$ for 20 minutes. The solution was taken and filtered with paper Whatman N.41 with the help of vacuum pump, and the residue was then transferred to the cup and dried. The residues were analysed for $\mathrm{N}$ by the KJELDAHL method, and considered as the rumen undegradable protein (Licitra et al. 1995).

After the supernatant was disposed of, the residues were centrifuged in a tube fermentor then dissolved in $30 \mathrm{ml}$ solution a pepsin- $\mathrm{HCl}(0.2 \%)$ and incubated for 48 hours in the aerobic condition at $39-40^{\circ} \mathrm{C}$. Then solution was filtered with Whatman N.41 paper with the help of vacuum pump. The residues was then dried in an oven at $105^{\circ} \mathrm{C}$ for 24 hours and weighed to calculate the dry matter degradable (IVDMD). The sample then dried in the electric furnace at a $600^{\circ} \mathrm{C}$ for 24 hours to determine the degradable organic matter (IVDOM). The residue was used to analyzed the $\mathrm{N}$ content for the calculating of degradable crude protein (IVCPD). IVCPD was calculated as the difference between the crude protein content of the samples before being incubated and after being incubated.

\section{In Vitro gas production}

Total gas production was measured according to the procedures of Close \& Menke (1986). Syringes (50 ml) were filled with $0.2 \mathrm{~g}$ sample and then added $30 \mathrm{ml}$ of rumen liquid that has been mixed with a buffer solution (1:2). The syringes are then inserted into a shaker water bath at $39^{\circ} \mathrm{C}$. Gas production was measured at 2 , $4,6,8,12,24$, and 48 hours of fermentation by noting the volume of gas formed during the process of fermentation.

\section{Statistical analysis}

The physical characteristic evaluation was arranged in a completely randomized design of four treatment (composition of green concentrate pellet) with three replicates. The in vitro study was arranged in a randomized block design with rumen liquid sampling time the block consisting of four treatments with three replicates. Data were analysed using the method of e Analysis of Variance (ANOVA). Uses software SAS version 9.1 (2002). The means were compared using the Duncan test (Steel \& Torrie 1995).

\section{RESULTS AND DISCUSSION}

\section{Chemical compositions}

The nutrient compositions of the green concentrates were shown Table 2. The dry matter (DM) and organic matter $(\mathrm{OM})$ content were relatively comparable among all treatments. The DM and OM contents ranged from 93.87 to $95.62 \%$ and from $89.65-91.11 \%$, respectively.

The crude protein $(\mathrm{CP})$ contents were numerically higher when the inclusion level of I. zollingeriana increased which is due to the higher crude protein content of I. zollingeriana compared to C. calothyrsus (Tarigan et al. 2010). The crude protein content of the green concentrates pellets ranged from 18.82 to $21.44 \%$. The high crude protein content of green concentrates pellet based on the mixtures I.zollingeriana and C. calothyrsus, is expected to increase productivity of ruminants through increasing of the flux of dietary protein for absorption in the intestines, and improving the amount of amino acid absorbed from intestinal digestion (Bach et al. 2005; Patra \& Saxena 2011). The content of crude fibers is relatively low and ranged from 8.95 to $12.04 \%$. 
Table 2. Chemical compositions of green concentrate pellets (\% DM)

\begin{tabular}{lcccccc}
\hline \hline \multirow{2}{*}{ Parameter } & \multicolumn{2}{c}{ Experimental forage } & \multicolumn{3}{c}{ Experimental diets } \\
\cline { 2 - 7 } & I. zollingeriana & C. calothyrsus & R0 & R1 & R2 & R3 \\
\hline Dry matter (DM) & 20.40 & 33.30 & 95.62 & 95.15 & 93.87 & 94.05 \\
Organic matter (OM) & 90.85 & 93.40 & 89.79 & 89.65 & 90.77 & 91.11 \\
Crude protein (CP) & 25.78 & 18.83 & 21.44 & 20.49 & 19.17 & 18.82 \\
Crude fiber (CF) & 14.25 & 11.70 & 12.04 & 10.25 & 8.95 & 9.35 \\
NDF & 35.64 & 47.70 & 42.18 & 40.20 & 38.30 & 33.13 \\
ADF & 24.64 & 33.90 & 27.70 & 21.10 & 17.29 & 18.02 \\
Total tannin & 0.85 & 12.76 & 0.85 & 2.75 & 3.79 & 5.56 \\
\hline
\end{tabular}

The NDF and ADF content range from 33.13 to $42.18 \%$, and from 17.29 to $27.70 \%$, respectively. These level of NDF and ADF contents seem not cause restrict feed consumption when fed to ruminant animals. (Van Soest et al.1991; De Boever et al. 2005).

The content of the total tannin in $\mathrm{R} 0(8.50 \mathrm{~g} / \mathrm{kg}$ $\mathrm{DM})$ is classified as very low, far below the threshold level $(50 \mathrm{~g} / \mathrm{kg} \mathrm{DM})$ that could express its role as anti of nutrient (Min et al. 2003; Al-Dobaib 2009; Piluzza et al. 2013). In line with the increasing inclusion level of $C$. calothyrsus the total tannin content increased in R1, $\mathrm{R} 2$, and R3 (2.75, 3.79, 5,56\%, respectively). Tannin was related to the protection of dietary protein against increasing the flux of dietary protein for absorption in the intestines and may result improving the amount of amino acid absorbed from intestinal digestion (Jayanegara et al. 2009; Szumacher-Strabel \& Cieslak 2010; Goel \& Makkar 2012). The use of tannin in rations feed on certain concentration can improve efficiency nutrients, increase the productivity of ruminants. To increase the use of protein feed, especially feed with level degradation rumen high required protection. Protection protein intended to reduce the level of degradation protein in the rumen but digested by an enzyme post-ruminally so that directly can use through a process absorption post-ruminally in the small intestines. One way protection protein with a coating is to the tannin (Smith et al. 2005; Patra \& Saxena 2011).

\section{Physical qualities}

The value of water activity (Aw) on green pellet feed concentrates based I. zollingeriana combined with $C$. calothyrsus (treatment) shown in Table 3. It is shown that the value of the water activity (Aw) green concentrate pellets with composition of R3 $(45 \% \mathrm{I}$. zollingeriana and $45 \%$ C. calothyrsus) were lower $(\mathrm{P}<0.05)$ compared to those with composition of $90 \%$ or $60 \%$ I. zollingeriana, but similar to those with composition of $75 \%$ I.zollingeriana and $15 \% C$. calothyrsus. The value of water activity obtained in this study are low ranging from 0.49 to 0.60 . It has been known that microbes can only grow in materials with specific water activity and materials having water activity of 0.7 is considered to be sufficient for lasting storage (Winarno 1991). The relatively low water activity values of green concentrate pellets found in this study is indicative of its potential for long lasting storage. The pelleting process could be defined as the agglomeration of small particles using a mechanical process in combination with moisture, heat, and pressure (Abdollahi et al. 2013). The particles size of green concentrate pellets is shown in Table 3 . The particle size of the green concentrate pellets was lowest in that with composition of $45 \%$ I. zollingeriana and $45 \%$ C. calothyrsus and there were no differences $(\mathrm{P}>0.05)$ among other treatments. The particle size of green concentrate pellets in all treatments ranged from 12.12 to $13.24 \mathrm{~mm}$. It was reported that the particle size of pellets was influenced by the particle size of its ingredients, and the smaller the particle size of its ingredients was the smaller the particle size of the pellets (Saenab et al. 2010). Amerah et al. (2007) reported that pelleting reduced the relative proportion of materials with particle size of $>1.0 \mathrm{~mm}$ and increased the proportion of those with particle size $<0.075 \mathrm{~mm}$ in coarse diets.

The degree of angles of repose of green concentrate pellets was not different $(\mathrm{P}>0.05)$ among the treatments and ranged from 18.06 to 21.01. Angulo (1995) confirm that materials that can easily flow will have degree of angles of repose ranging from 20 to $30^{\circ}$. When compared to these values the green concentrate pellets of various composition of $I$. zollingeriana and $C$. calothyrsus would easily flow across the compartments within the whole feed processing system. This trait is important in improving the efficiency of feed processing. 
Table 3. Physical qualities green concentrates pellets based I. zollingeriana in combination with C. calothyrsus

\begin{tabular}{|c|c|c|c|c|}
\hline \multirow{2}{*}{ Parameter } & \multicolumn{4}{|c|}{ Treatment } \\
\hline & R0 & R1 & $\mathrm{R} 2$ & $\mathrm{R} 3$ \\
\hline Water activity (Aw) & $0.60 \pm 0.08^{\mathrm{a}}$ & $0.54 \pm 0.01^{\mathrm{ba}}$ & $0.58 \pm 0.01^{\mathrm{a}}$ & $0.49 \pm 0.02^{\mathrm{b}}$ \\
\hline Particles size (mm) & $13.16 \pm 0.14^{\mathrm{ba}}$ & $13.24 \pm 0.13^{\mathrm{a}}$ & $12.69 \pm 0.71^{\mathrm{ba}}$ & $12.12 \pm 0.81^{\mathrm{b}}$ \\
\hline Degree value angles $\left(^{\circ}\right)$ & $18.84 \pm 1.11$ & $18.06 \pm 0.45$ & $21.01 \pm 1.40$ & $19.04 \pm 3.59$ \\
\hline Collision endurance $(\%)$ & $99.84 \pm 0.06^{\mathrm{ba}}$ & $99.90 \pm 0.01^{\mathrm{a}}$ & $99.78 \pm 0.05^{\mathrm{b}}$ & $99.65 \pm 0.06^{\mathrm{c}}$ \\
\hline Friction endurance $(\%)$ & $92.53 \pm 0.70^{\mathrm{a}}$ & $92.92 \pm 1.46^{\mathrm{a}}$ & $90.42 \pm 0.41^{\mathrm{a}}$ & $87.19 \pm 2.50^{\mathrm{b}}$ \\
\hline Bulk density $\left(\mathrm{kg} / \mathrm{m}^{3}\right)$ & $590 \pm 0.03$ & $640 \pm 0.02$ & $590 \pm 0.02$ & $570 \pm 0.00$ \\
\hline
\end{tabular}

${ }^{\mathrm{a}, \mathrm{b}, \mathrm{c}}$ means within a row without a common superscript letter differ significantly

Collision endurance is variable that is used to test endurance of pellets to collision. The collision endurance of green concentrate pellets R3 composed of $45 \%$ I. zollingeriana and $45 \% \quad C$. calothyrsus was lowest $(\mathrm{P}<0.05)$, but it was not different among other treatments (Table 3). The range of collision endurance values of the green concentrate pellets was 99.65 to $99.90 \%$ which are slightly higher compared to the study of Saenab et al. (2010) in complete pellet feed containing hydrolysates of shrimp by-products having collision endurance ranging from 92.25 to $99.34 \%$. The gelatinizing process may help to form a string ties among the particles that resulted in improving a compact pellet feed (Cheeke 1999).

Friction endurance value (durability) of green concentrate pellets significantly $(\mathrm{P}<0.05)$ increased as the proportion of $I$. zollingeriana in the green concentrate increased. The friction endurance value (durability) of green concentrate pellet ranged from 87.19 to $92.92 \%$. These values are numerically greater than the minimum friction endurance value (durability) of $80 \%$ reported by Dozier (2001). The relatively high friction endurance values of green concentrate pellets in the present study could be affected by low the moisture content and small particle size of materials used to produce the green concentrate pellet so that they were compact and not easily destroyed by friction. The smaller the size of particles of materials the larger are the surface area for particles to contact and to form a strong bound among the particles which then cause the pellets are not easily destroyed (Saenab et al. 2010).

The bulk density was not affected $(\mathrm{P}>0.05)$ by the composition of the green concentrate pellet (Table 3 ). The bulk density of the pellet was in the range of 570 to $640 \mathrm{~kg} / \mathrm{m} 3$. Numerically, the bulk density was highest in green concentrate pellet composed of $75 \% \mathrm{I}$. zollingeriana $(640 \mathrm{~kg} / \mathrm{m} 3)$ and was lowest in that composed of $45 \%$ I. zollingeriana $(570 \mathrm{~kg} / \mathrm{m} 3)$. Kahlil (1999a) stated that feed having low bulk density $(<450$ $\mathrm{kg} / \mathrm{m} 3$ ) require longer flowing time flows (vertical direction) and vice versa with other feed which have the bulky density $>500 \mathrm{~kg} / \mathrm{m} 3$ ). Materials in the form of pellets or tube having bulky density of $600-800 \mathrm{~kg} / \mathrm{m}^{3}$ are easier to handle, delivery, storage and to use (Kaliyan \& Morey 2009). The bulky density of green concentrates pellets in the present study is considered to be relatively high indicating that handling of these pellet feed will be easy and less space is needed to store. Khalil (1999a) reported that feeds with high bulk density need a period of falling and flowing more concise than those with lower bulk density.

\section{In Vitro rumen degradability}

The in vitro rumen degradability of green concentrate pellets based on mixtures of I. zollingeriana and $C$. calothyrsus is shown in Table 4. IVDMD and IVOMD of pellet composed of $90 \%$ I. zollingeriana were significantly higher $(\mathrm{P}<0.05)$ compared to other treatment. The IVDMD and IVOMD increased in line with the increasing proportion of I. zollingeriana and decreasing proportion of $C$. calothyrsus. The higher content of tannin in $C$. calothyrsus may contributed to this phenomenon as indicated by the highest tannin content $(55.6 \mathrm{~g} / \mathrm{kg})$ of those green concentrate pellet with the highest proportion of C. calothyrsus (Table 2). This tannin level is beyond the threshold of $50 \mathrm{~g} / \mathrm{kg} \mathrm{DM}$ that has a decreasing effect on the rate of protein degradation (Min et al. 2003; Al-Dobaib 2009; Piluzza et al. 2013). Thus, an increase in the tannin content in any green concentrates pellets composition is tending to cause decreases in IVDMD and IVOMD. Suharlina et al. (2016) reported that feed concentrates composing of $20 \%$ I. zollingeriana has a high in vitro degradability due to its high content of crude protein (CP) and low content of crude fibers. Increasing nitrogen content in forage mixtures by adding legumes have been shown to improve ruminal digestion of feed dry matter (Dal Pizzol et al. 2017). In the present study, the IVDMD and IVOMD of green concentrate pellets may have been positively influenced by high $\mathrm{CP}$ content of I. zollingeriana. 
IVCPD of green concentrates pellet were no significantly different $(\mathrm{P}>0.05)$ among treatments, except that IVCPD was lowest $(\mathrm{P}<0.05)$ in that composed of $45 \%$ I. zollingeriana and $45 \% \quad C$. calothyrsus (Table 4). IVCPD values ranged from 77.65 to $86.78 \%$ in all treatments with the highest values obtained in the pellet composed of $90 \%$ I. zollingeriana $(86.78 \%)$. The increasing level of $I$. zollingeriana in the green concentrate pellets linearly increased the crude protein content of the pellets (Table 2).This increase of the crude protein in diet may trigger the activity of microbial fermentation in the rumen (Kiran \& Mustsvangwa 2009; Sauve et al. 2009). This indicates that the green concentrate may have provided sufficient $\mathrm{N}$ to favor the growth rumen microbes that serves as a source of protein for of ruminants. IVCPD obtained in the present study are higher than those reported by Suharlina et al. (2016) ranging from 79.1 to $83.38 \%$ on diets composed of 0.20 and $40 \%$ I. zollingeriana fed to goats. The relatively high digestibility of these green concentrate pellets could also be affected by the process (grinding, pressuring, and heating) that has been put on ingredients in producing the pellets. The application of heat and pressure during pelleting might promote starch gelatinisation which increased the fermentation rate (Solanas et al. 2008).

RDP of green concentrate pellets was affected by the composition of the pellet $(\mathrm{P}<0.05)$. The greatest RDP was observed in pellet with highest level proportion of I. zollingeriana and decrease in line with increasing proportion of $C$. calothyrsus. This indicates that solubility of the protein in green concentrate tend to rise as the proportion of I. zollingeriana is increasing. This is in agreement with the fact that I. zollingeriana has high protein content with high degradability in the rumen and low fiber and tannin contents (Tarigan et al. 2010; Suharlina et al. 2016).

The RUP of green concentrates composed of $45 \% \mathrm{I}$. zollingeriana and $45 \%$ C. calothyrsus was higher compared to that composed of $60 \%$ I. zollingeriana and
$30 \%$ C. calothyrsus or $90 \%$ I. zollingeriana and $0 \%$ C. calothyrsus, but was not different to that composed of $75 \%$ I. zollingeriana and $15 \%$ C. calothyrsus. The ranking order of the green concentrate pellet in term of their RUP values was $R 3>R 2 \geq R 1>R 0$. RUP value increase in line with the increased proportion of $C$. calothyrsus in the mixture with $I$. zollingeriana. Combination of high-tannin forages with other highly fermentable forages will improve microbial protein synthesis and microbial growth efficiency (Soltan et al. 2012). Tannin is beneficial to form a complex with protein in the rumen for supplying protein to the digestive tract after rumen, to increase productivities of ruminants (Al-Dobaib 2009; Jayanegara et al. 2011b; Piluzza et al. 2013). This indicates the potential of green pellets concentrates for supplying protein needs of ruminants after rumen.

\section{Characteristic of fermentation rumen}

The $\mathrm{pH}$ values of the media (in vitro) were not affected $(\mathrm{P}>0.05)$ by the composition of $I$. zollingeriana and $C$. calothyrsus of the green concentrate pellets (Table 5). The lowest $\mathrm{pH}(\mathrm{P}>0.05)$ was observed in media where substrate used was the mixture of $I$. zollingeriana (45\%) and C. calothyrsus $45 \%$. Nevertheless, there was a trend of decreasing $\mathrm{pH}$ of in vitro media when the proportion of $C$. calothyrsus in substrates increase. The $\mathrm{pH}$ levels obtained in the present study ranged from 6.73 to 6.75 and is relatively lower compared to those reported by Syahrir et al. (2009), i.e., 6.9-7.0 when using flour mulberry as substrates. This $\mathrm{pH}$ levels are at least in the range of 6.2-7.2 reported by Van Houtert (1993) and Van Soest (1994) to ensure optimal ruminal digestion.

The ammonia-N (NH3-N) concentration $(9.32 \mathrm{mM})$ was highest $(\mathrm{P}<0.05)$ when $90 \%$ I. zollingeriana was used as substrate, but it was not different $(\mathrm{P}>0.05)$ to that when $75 \%$ I. zollingeriana and $15 \%$ C. calothyrsus was used as substrates $(8.21 \mathrm{mM})$. The concentrations

Table 4. In vitro rumen degradability green pellets concentrates based I. zollingeriana in the combination with $C$. calothyrsus $(\% \mathrm{DM})$

\begin{tabular}{lcccc}
\hline \hline \multirow{2}{*}{ Parameter } & \multicolumn{3}{c}{ Treatment } \\
\cline { 2 - 5 } & $\mathrm{R} 0$ & $\mathrm{R} 1$ & $\mathrm{R} 2$ & $\mathrm{R} 3$ \\
\hline IVDMD (\%) & $73.62 \pm 1.30^{\mathrm{a}}$ & $66.58 \pm 2.65^{\mathrm{b}}$ & $60.09 \pm 0.91^{\mathrm{c}}$ & $53.47 \pm 1.63^{\mathrm{d}}$ \\
IVOMD (\%) & $71.84 \pm 1.80^{\mathrm{a}}$ & $64.29 \pm 1.08^{\mathrm{b}}$ & $57.58 \pm 1.11^{\mathrm{c}}$ & $50.43 \pm 2.01^{\mathrm{d}}$ \\
IVCPD (\%) & $86.78 \pm 0.96^{\mathrm{a}}$ & $85.59 \pm 5.87^{\mathrm{a}}$ & $84.07 \pm 2.81^{\mathrm{ba}}$ & $77.65 \pm 2.41^{\mathrm{b}}$ \\
RDP (\%) & $54.35 \pm 0.54^{\mathrm{a}}$ & $47.00 \pm 0.92^{\mathrm{b}}$ & $48.08 \pm 2.5^{\mathrm{b}}$ & $42.47 \pm 3.27^{\mathrm{c}}$ \\
RUP (\%) & $45.65 \pm 0.54^{\mathrm{c}}$ & $53.00 \pm 0.92^{\mathrm{b}}$ & $51.92 \pm 2.5^{\mathrm{b}}$ & $57.54 \pm 3.27^{\mathrm{a}}$ \\
\hline
\end{tabular}

a,b,c,d Means within a row without a common superscript letter differ significantly RDP - rumen degradable protein; RUP-rumen undegradable protein 
Table 5. Characteristic fermentation rumen concentrate green pellet based I. zollingeriana in the the combination with $C$. calothyrsus

\begin{tabular}{lcccc}
\hline \multirow{2}{*}{ Parameter } & \multicolumn{3}{c}{ Treatment } \\
\cline { 2 - 5 } & \multicolumn{1}{c}{ R0 } & R1 & R2 & $6.73 \pm 0.03$ \\
pH & $6.75 \pm 0.05$ & $6.75 \pm 0.05$ & $6.73 \pm 0.06$ & $6.30 \pm 0.67^{\mathrm{c}}$ \\
N-NH3 (mM) & $9.32 \pm 1.25^{\mathrm{a}}$ & $8.21 \pm 0.50^{\mathrm{ba}}$ & $7.51 \pm 0.66^{\mathrm{b}}$ & $78.31 \pm 5.57^{\mathrm{d}}$ \\
Total VFA (mM) & $138.12 \pm 7.57^{\mathrm{a}}$ & $117.45 \pm 7.09^{\mathrm{b}}$ & $95.50 \pm 3.21^{\mathrm{c}}$ & $6.51 \pm 0.45$ \\
Total bacteria (LogCFU/ml) & $6.69 \pm 0.31$ & $6.24 \pm 0.06$ & $6.45 \pm 0.34$ &
\end{tabular}

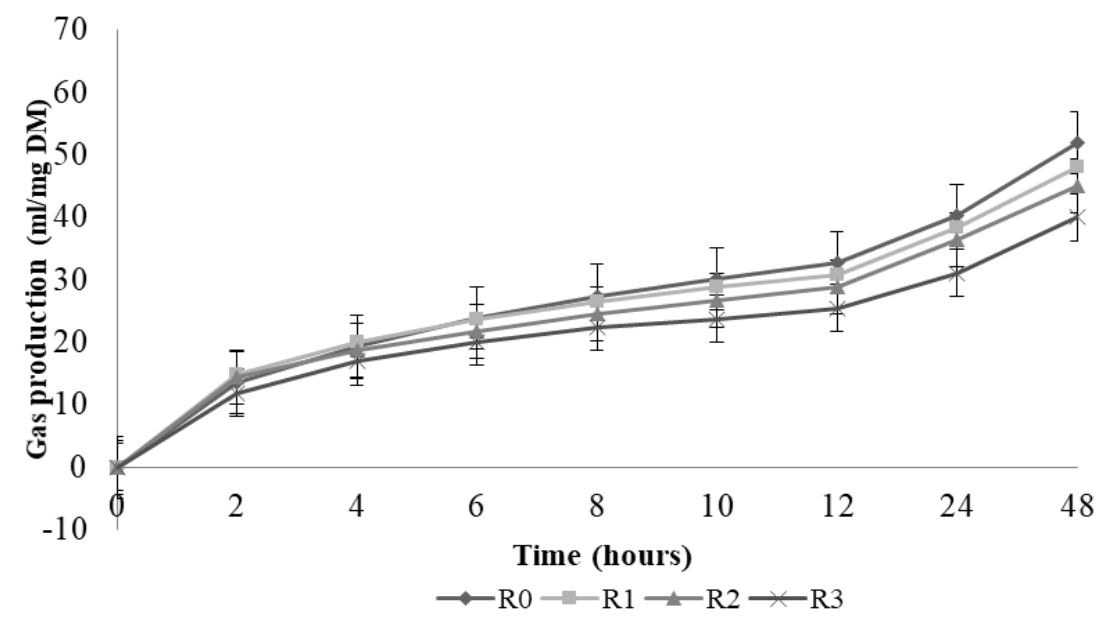

Figure 1. Total gas production of feed green concentrate pellets in different combination I. zollingeriana/C. calothyrsus (90/0; R0), I. zollingeriana/C. calothyrsus $(75 / 15 ; \mathrm{R} 1)$, I. zollingeriana/C. calothyrsus $(60 / 30 ; \mathrm{R} 2)$ and I. zollingeriana/C. calothyrsus $(45 / 45 ; \mathrm{R} 3)$.

ruminal $\mathrm{NH}_{3}-\mathrm{N}$ of all treatments ranged from 6.30 to $9.32 \mathrm{mM}$. McDonald et al. (2010) stated that the concentration $\mathrm{NH}_{3}-\mathrm{N}$ required to support protein of rumen microbes ranged from 85 to $300 \mathrm{mg} / \mathrm{l}$ or $6-12$ $\mathrm{mM}$. The increased proportion of I. zollingeriana tends to increase the concentrates of $\mathrm{NH}_{3}-\mathrm{N}$ of the rumen liquid which may related to the increased protein level of the green concentrate. The $\mathrm{NH}_{3}-\mathrm{N}$ concentration of the rumen liquid observed in this study is higher compared to $3.87-5.23 \mathrm{mM}$ reported by Suharlina et al. (2016).

The concentration of total VFA in the rumen liquid was highest when $90 \%$ I. zollingeriana was used as substrate. As the proportion of I. zollingeriana in the green concentrate pellet increased the VFA concentration tent to increase. The VFA concentration ranged from 78.3 to $138.12 \mathrm{mM}$ and in parallel with the normal range 78.81 to $138.2 \mathrm{mM}$ reported by Wanapat \& Pimpa (1999). There was a decrease of $33 \%$ in the VFA concentration of the rumen liquid when the proportion of I. zollingeriana deceased from 90 to $45 \%$ in the mixtures of I. zollingeriana and C. calothyrsus.
Total bacteria number was not different $(\mathrm{P}<0.05)$ among treatments and ranged from 6.24-6.69 log $\mathrm{CFU} / \mathrm{ml}$. Numerically, total rumen bacteria numbers were higher when $90 \%$ I. zollingeriana was used as substrate.

\section{In Vitro gas production}

Total gas production for 48 hour incubation period of green concentrate pellets is presented in Figure 1. Total gas production obtained at all treatments ranged from 38 to $52 \mathrm{ml}$ which are numerically higher compared to 20.31-24.83 ml reported by Suherlina et al. (2016) worked on feed concentrates based on $I$. zollingeriana in vitro. The gas production was highest $(\mathrm{P}<0.05)$ when green concentrate pellet composed of $90 \%$ I. zollingeriana was incubated. The gas production tent to increase as the proportion of I. zollingeriana in the green concentrate pellets increased and which may related to the it's higher crude protein and lower fiber contents that could trigger increased feed digestion. The study of Tschernig et al. (2006) showed that addition of 
I. zollingeriana increases the rate of the production of gas and degradation $\mathrm{N}$ more than $C$. calothyrsus. The gas production curve of all treatments showed a linear fashion over the 48 hour-incubation periods. This is indicative of the presence of substrates that are readily fermented provided that incubation period was prolonged over 48 hours period.

\section{CONCLUSION}

It can be concluded that inclusion of Calliandra calothyrsus did not change physical quality of green pellets. However, increasing level of $C$. calothyrsus increased RUP and reduced digestibility, $\mathrm{N}-\mathrm{NH}_{3}$, and total VFA.

\section{REFERENCES}

Abdullah L, Tarigan A, Suharlina, Budhi D, Jovintry I, Apdini TA. 2012a. Indigofera zollingeriana: A promising forage and shrubby legume crop for Indonesia. Astuti DA, editor. Proceeding the 2nd International Seminar on Animal Industry. Jakarta (Indones): Bogor Agricultural University. p. 149-153.

Abdullah L, Apdini T, Astuti DA. 2012b. Use of Indigofera zollingeriana as a forage protein source in dairy goat rations. Abdullah R, Omar MA, Makkar H, Otte J, Rajion MA, Alimon AR, Boo LJ, Kam HA. Li CW, editors. Proceeding of the $1^{\text {st }}$ Asia Dairy Goat Conference. Kuala Lumpur (Malays): Universiti Putra Malaysia and The Food and Agricultural Organization of the United Nations. p. 72-74.

Abdollahi MR, Ravindran V, Shihus B. 2013. Pelleting of broiler diets: An overview with emphasis on pellet quality and nutritional value. Anim Feed Sci Tech 179:1-23.

Al-Dobaib SN. 2009. Effect of different levels of quebracho tannin on nitrogen utilization and growth performance of Najdi sheep fed alfalfa (Medicago sativa) hay as a sole diet. J Anim Sci. 80:532-541.

Amerah AM, Ravindran V, Lentle RG, Thomas DG. 2007. Influence of feed particle size and feed form on the performance, energy untilisation, digestive tract development and digesta parameters of broiler starters. J Poult Sci. 86:2615-2623.

Angulo EJ, Brufu EE. Garcia. 1995. Effect of sepoilite on pellet durability in feeds differing in fat and fiber content. J Anim Feed Technol. 53:233-241.

[AOAC] Association of Official Analytical Chemists. 2005. Official methods of analysis. 2005. 18th ed. Washington DC (USA): Association of Official Analytical Chemists.

Bach A, Calsamiglia S, Stern MD. 2005. Nitrogen metabolism in the rumen. J Dairy Sci. 88:E9-E21.
Balagopolan C, Padmaja G, Nanda SK, Moorthhy SN. 1988. Cassava in food: Feed Industry. Florida (USA): IRC Press.

Bertipaglia LMA, Fondevila M, van Laar H, Castrillo C. 2010. Effect of pelleting and pellet size of a concentrate for intensively reared beef cattle on in vitro fermentation by two different approaches. Anim Feed Sci Technol. 159:88-95.

Cheeke PR. 1999. Applied animal nutrition: Feeds and feeding. 2nd ed. New Jersey (USA): Prentice Hall.

Close W, Menke KH. 1986. Manual selected tropics in animal nutrition. 2nd ed. Stuttgart (Germany): The Institute of Animal Nutrition, University of Hohenhelm.

Dal Pizzol JG, Ribeiro-Filho HMN, Quereuil A, Le Morvan A, Niderkorn V. 2017. Complementarities between grasses and forage legumes from temperate and subtropical areas on in vitro rumen fermentation characteristics. Anim Feed Sci Technol. 228:178-185.

De Boever JL, Aerts JM, Vnacker JM, De Brabander DL. 2005. Evaluation of the nutritive value of maize silages using a gas production technique. Anim Feed Sci Technol. 123-124:255-265.

Department of Dairy Science. 1966. General laboratory procedures. Medison (USA): University of Wisconsin.

Dozier WA. 2001. Pellet quality for more economical poultry meat. J Feed Int. 52:40-42.

Fairfield D. 1994. Pelleting cost center. In: McEllhiney R, editor. Feed Manufacturing Technology IV. Arlington, VA (USA): American Feed Industry Association. p. 121-122.

Ginting SP, Krisnan R, Sirait J. 2010. The utilization of Indigofera $\mathrm{sp}$ as the sole foliage in goat diets supplemented with high carbohydrate or high protein concentrates. JITV. 15:261-268

Goel G, Makkar HPS. 2012. Methane mitigation from ruminants using tannins and saponins, a status review. J Trop Anim Health Prod. 44:729-739.

Hess HD, Mera ML, Tiemann TT. 2008. In Vitro assessment of the suitability of replacing the low-tannin legume Vigna unguiculata with the Tanniniferous legumes Leucaena leucocephala, Flemingia macrophylla or Calliandra calothyrsus in a tropical grass diet. Anim Feed Sci Technol. 147:105-115.

Jayanegara A, Togtokhbayar N, Makar HPS, Becker K. 2009. Tannins determined by various methods as predictors of methane production reduction potential of plants by an in vitro rumen fermentation system. J Feed Sci Technol. 150:230-237.

Jayanegara A, Wina E, Soliva CR, Marquardt S, Kreuzer M, Leiber F. 2011a. Dependence of forage quality and methanogenic potential of tropical plants on their phenolic fractions as determined by principal component analysis. Anim Feed Sci Technol. 163: 231-243. 
Jayanegara A, Leiber F, Kreuzer M.2011b. Meta-analysis of the relationship between dietary tannin level and methane formation in ruminants from in vivo and in vitro experiments. J Anim Phsiol Anim Nutr. 96:265375.

Kaliyan N, Morey RV. 2009. Factors affecting strength and durability of densified biomass products. J Biomass Bioenergy. 33:337-359.

Khalil. 1999a. Pengaruh kandungan air dan ukuran partikel terhadap sifat fisik pakan lokal, kerapatan tumpukan, pemadatan tumpukan, dan berat jenis. Media Peternakan. 22:1-11.

Khalil. 1999b. Pengaruh kandungan air dan ukuran partikel terhadap perubahan perilaku fisik bahan pakan lokal, sudut tumpukan, daya ambang dan faktor higroskopis. Media Peternakan. 22:33-42.

Kholif AE, Gauda GA, Morsy TA, Salem AZM, Lopez S, Kholif AM. 2015. Moringa Oleifera meal as a protein source in lactating goat's diets: Feed intake, digestibility, ruminal fermentation, milk yield and composition, and its fatty acids profile. Small Rumin Res. 129:129-137.

Kiran D, Mutsvangwa T. 2009. Nitrogen utilization in growing lambs fed oscillating dietary protein concentration. Anim Feed Sci Technol. 152:33-41.

Licitra G, Hernandez TM, Van Soest PJ. Standardization of procedures for nitrogen fractionation of ruminant feeds. Anim Feed Sci Technol. 57:347-358.

Makkar HPS. 2003. Quantification of tannin in tree an shrub foliage. A laboratory manual. Dordrecht (Netherlands): Kluwer Academic Publisher.

McDonald P, Edward RA, Greenhalgh JFD, Morgan CA, Sinclair LA, Wilkinson RG. 2010. Animal nutrition. 7th ed. New York (USA): Scientific and Tech John Willey \& Sons, Inc.

Min BR, Barry TN, Attwood GT, McNabb WC.2003.The effect of condensed tannin on the nutrition and health of ruminants fed fresh temperate forage: A review. Anim Feed Sci Technol. 106:3-19.

Norton BW. 1994. Tree legumes as dietary supplements for ruminants. In: Gutteridge RC, Sheiton HM, editors. Forage tree legumes in tropical agriculture. Wallingford (UK): CAB International. p. 15-30.

Olafadehan OA, Adewumi MK. 2009. Productive and reproductive performance of strategically supplemented free grazing prepartum Bunaji cows in the agropastoral farming system. Trop Anim Health Prod. 41:1275-1281.

Patra AK, Saxena J. 2011. Exploitation of dietary tannins to improve rumen metabolism and ruminant nutrition. J Sci Food Agric. 91:24-37.

Piluzza G, Sulas L, Bullitta S. 2013. Tannis in forage plants and their role in animal husbandry and environmental sustainability: a review. J Grass Forage Sci. 69:32-48.
Saenab A, Laconi EB, Retnani Y, Mas'ud MS. 2010. Evaluasi kualitas pelet ransum komplit yang mengandung produk samping udang. JITV. 15:31-39.

[SAS] Statistical Analysis System Institute. 2002. Statistical analysis system. Version 9.1.3. Cary NC (USA): SAS Institute Inc.

Sauve AK, Huntington GB, Burns JC. 2009. Effects of total nonstructural carbohydrates and nitrogen balance on voluntary intake of goats and digestibility of gamma grass hay harvested at sunrise and sunset. Anim Feed Sci Technol. 148:93-106.

Smith AH, Zoetendal E, Mackie RI. 2005. Bacterial mechanisms to overcome the inhibitory effect of dietary tannins. J Microb Ecol. 50:197-205.

Solanas E, Castrillo C, Fondevila M, Ruiz Narvaez QO, Guada JA. 2005. Effect of concentrate extrusion and castration on diet digestion and performance of intensively reared male calves. Livest Prod Sci. 94: 225-236.

Solanas E, Castrillo C, Fondevila M, Ruiz Narvaez QO, Guada JA. 2008. Effects of cereals and/or protein supplement extrusion on diet utilisation and performance of intensively reared cattle. Livest Sci. 117:203-214.

Soltan YA, Morsy AS, Louvandini H, Abdalla AL. 2012. Comparative in vitro evaluation of forage legumes (Prosopis, Acacia, Atriplex, and Leucaena) on ruminal fermentation and methanogenesis. J Anim Feed Sci. 21:759-772.

Steel RGD, Torrie JH. 1995. Prinsip dan prosedur statistika. 2nd ed. Sumantri B, translator. Translate from: The Principle and Procedure of Statistics. Jakarta (Indones): Gramedia Pustaka Utama.

Suharlina, Astuti DA, Jayanegara A, Abdullah L. 2016 Nutritional evaluation of dairy goat rations containing Indigofera zollingeriana by using in vitro rumen fermentation technique (RUSITEC). Int J Dairy Sci. 11:100-105.

Svihu B, Zimonja O. 2011. Chemical alterations with nutritional consequences due to pelleting animal feeds: A review. Anim Prod Sci. 51:590-596.

Svihu B. 2011. The gizzard: Function, Influence of diet structure and effects on nutrient availability. World's Poult Sci J. 67:207-223.

Syarief R, Halid H. 1993. Teknologi penyimpanan pangan. Jakarta (Indones): Penerbit ARCAN.

Szumacher-Strabel M, Cieslak A. 2010. Potential of phytofactors to mitigate rumen ammonia and methane production. J Anim Feed Sci. 19:319-337.

Syahrir S, Wiryawan KG, Parakkasi A. 2009. Efektivitas daun murbei sebagai pengganti konsentrat dalam sistem rumen in vitro. Media Peternakan. 32:112-119.

Tarigan A, Ginting SP. 2011. Pengaruh taraf pemberiaan Indigofera $S p$, terhadap konsumsi dan kecernaan pakan 
serta pertumbuhan bobot hidup kambing yang diberi rumput Brachiaria ruziziensis. JITV. 163:231-243.

Tarigan A, Abdullah L, Ginting SP, Permana IG. 2010 Produksi dan komposisi nutrisi serta kecernaan in vitro Indigofera $s p$ pada interval dan tinggi pemotongan berbeda. JITV. 15:188-195.

Theodoridou K, et al. 2010. Effects of condensed tannins in fresh sainfoin (Onobrychis viciifolia) on in vivo and in situ digestion in sheep. Anim Feed Sci Tech. 160:23-38.

Tilley JMA, Terry RA. 1963. A two-stage technique for the in vitro digestion of forage crops. J Grass Forage Sci. 18:104-111.

Tschernig L, Lascano K, Barrios E, Schultze-Kraft, Peters M. 2006. The effect of mixing prunings of two tropical shrub legumes (Calliandra houstoniana and $I$. zollingeriana) with contrasting quality on $\mathrm{N}$ release in the soil and apparent $\mathrm{N}$ degradation in the rumen. $\mathrm{J}$ Plant Soil. 280:357-368.
Van Houtert M. 1993. The production and metabolism of volatile fatty acids by ruminants fed roughages: A review. Anim Feed Sci Technol. 43:189-225.

Van Soest PJ, Robertson JB, Lewis BA. 1991. Methods for dietary fiber, neutral detergent fiber, and non-starch polysaccharides in relation to animal nutrition. J Dairy Sci. 74:3583-3597.

Van DTT, Nguyen TM, Inger Ledin. 2005. Tropical foliages: Effect of presentation method and species on intake by goats. Anim Feed Sci Technol. 118:1-17.

Wanapat M, Pimpa O. 1999. Effect of ruminal $\mathrm{NH}_{3}-\mathrm{N}$ level on ruminal fermentation, purine derivative, digestibility and rice straw intake in swamp buffaloes. Asian-Aust $\mathbf{J}$ Anim Sci. 12:904-907.

Winarno FG. 1991. Kimia pangan dan gizi. Cetakan ke-5. Jakarta (Indones): PT. Gramedia. 